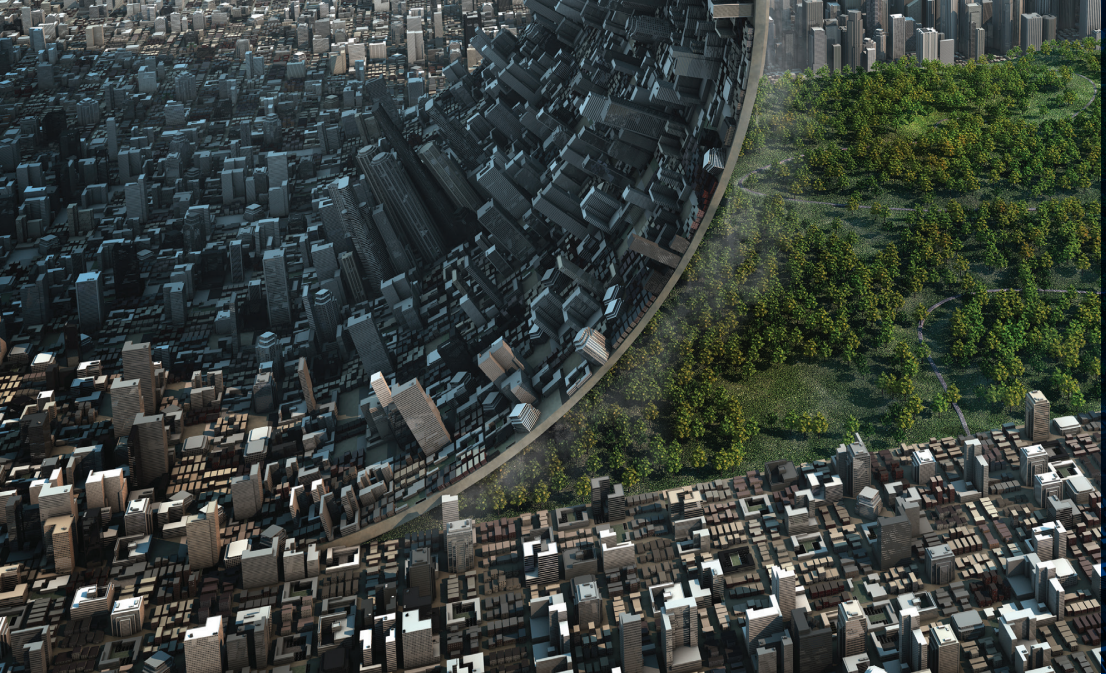
i.

\title{
BUSINESS
} AND THE ENVIRONMENT

editors

Tomasz Dorożyński

Anetta Kuna-Marszałek 


\title{
Chapter 1
}

\section{International trade and the environment}

\author{
Anetta Kuna-Marszałek
}

\subsection{Contemporary international trade - general tendencies}

Contemporary international trade has been developing as a result of liberalisation in the world economy, which has visibly accelerated its pace over the past few decades, and today takes place within the existing regional groupings and on the World Trade Organisation (WTO) forum. Nowadays, it would be difficult to find a single country not participating in international exchange. International transactions take place at a number of different levels, and in various forms or configurations, thus being far from the traditional understanding and perception of international trade. It is worth stressing that contemporary trade is not only about the exchange of goods and services, but increasingly, about trading in licenses, patent rights or - due to migrations - even capital. What is more, contemporary international trade is perceived as a factor that impacts economic development of countries and regions and reinforces economic transformation processes.

By international trade we mean the entirety of transactions between all countries or within groups of countries (most often under integrated structures). One can point to a number of factors shaping the development of international trade, namely: political (political or military conflicts at the international scale or the absence thereof) and economic factors (prosperity in international markets translates into increased demand, including imported goods), trade policies pursued by countries (liberalism/protectionism), technological (development of technologies, including modern development trends in means of transport and communication) as well as institutional factors resulting from the activities of international organisations (e.g. GATT, WTO, IMF). The pro-active attitude of the latter and their activities fostering liberalisation ideas usually lead to increased openness of trade and to the establishment of rules and regulations facilitating 
the execution of commercial transactions (e.g. settlement of commercial transactions). This applies also to procedures governing contractual arrangements or the rules for the application of commercial policy measures.

Since early 1960s, we have observed immense growth in world trade: between 1970 and 2013, the share of exports in global production doubled, and today it accounts for over $25 \%$ (www.wto.org 2015). In the early years of this period, elasticity of exports (the ratio of exports growth to production) was $1.5 \%$, while in 1986 it was already growing considerably, to reach over $2.5 \%$ by the end of the 1990s. This acceleration resulted from the fall of the centrally planned economies in Central and Eastern Europe as well as from the opening up of Chinese and Indian economies and their pro-export strategies (Dugiel 2000, p. 9).

The most important characteristics of contemporary international trade include:

- trade growth dynamics - changes in export and import dynamics are higher that the dynamics of GDP change, a growing share of exports in GDP is observed. Between 1948 and 2014, global exports in goods grew (in value terms) from USD 58bn to USD 18.5 trillion, i.e. over 300 times, whereas global GDP grew ca. 8 times within the same period (www.trademap.org 2015);

- the growing share of services in international trade (growth from $15 \%$ in 1980 to $26 \%$ in 2014). Currently, services represent ca. $65 \%$ of global GDP (in highly developed countries this share amounts on average to $75 \%$ ). In 2014, global exports of services exceeded USD 4 trillion, while the average annual growth rate in value terms was ca. 8\% (www.wto.org 2015);

- the growing share of developing countries in international trade in the exports of developed countries. Despite their constant domination in global trade, economically developed regions are gradually losing their importance. Their share in the world's exports in 2014 was only 55\%, whereas in 1995 it amounted to 70\%. Highly developed countries are gradually making room for the rapidly developing economies of South and East Asia and Latin America;

- the increase in intra-industry and intra-firm trade. This illustrates the growing dependence on the import of parts and components manufactured within the same branch of industry and even within the same corporation.

As mentioned above, trade in services, know-how and technological thought has been growing in importance in contemporary trade. This is a natural effect of 
the servitisation of developed economies, understood as the growth of the service sector in GDP and employment structures. All this takes place in the wider context of technological advancement, resulting from the exploitation of knowledge created within the process of education (Michalczyk 2007).

\subsection{International trade and demand for environment functions}

The environment performs two basic functions in the economy. Firstly, it is the source of natural resources, which means it provides natural commodities (e.g. water, air, soil and raw materials) to be used in economic activities. Its other function is in providing the possibility to remove waste produced as a result of human economic activities into the environment. Both functions were presented in detail by Budnikowski (1998, p. 67; see figure 1.1.), who divided natural resources into non-renewable (energy resources, metal ores depositions) and renewable (sea fish, forests). ${ }^{1}$

The negative impact of international trade upon the environment results from considerable growth in demand for both of the aforementioned functions due to intensified trade. International trade produces increased pressure on the natural environment and its resources in both direct and indirect ways. The direct impact is mainly the effect of greater intensity of transportation (growing demand for fuels, with fuel consumption leading to increased emissions of pollution to air, risk of ecological disasters) and excessive - compared to the capacity of local ecosystems - concentration of production (as a consequence of export specialisation patterns). The indirect impact is caused by the influence of international trade on economic growth. This, is turn, means greater demand for natural resources and increased emissions (due to resource extraction and processing).

International trade seriously overburdens the environment. Building and using roads and transportation networks, exploitation of arable land to grow ever increasing amounts of products, excessive extraction of resources, air pollution with exhaust fumes or storage of poisonous and radioactive waste, provide a justification for such an opinion. The scale of risks resulting from disturbances in environmental sustainability and the need to protect the environment are often used as an excuse to introduce barriers to global trade.

The difficulty in precisely estimating the impact of trade upon the environment is even greater if we consider how hard it is to identify the value of its

1 The division into renewable and non-renewable resources is a simplification. In literature on the subject, this division is much more complicated. Detailed classification of natural resources based on a number of different criteria, was provided, for example, by Jakubczyk (2002, p. 122-125). 


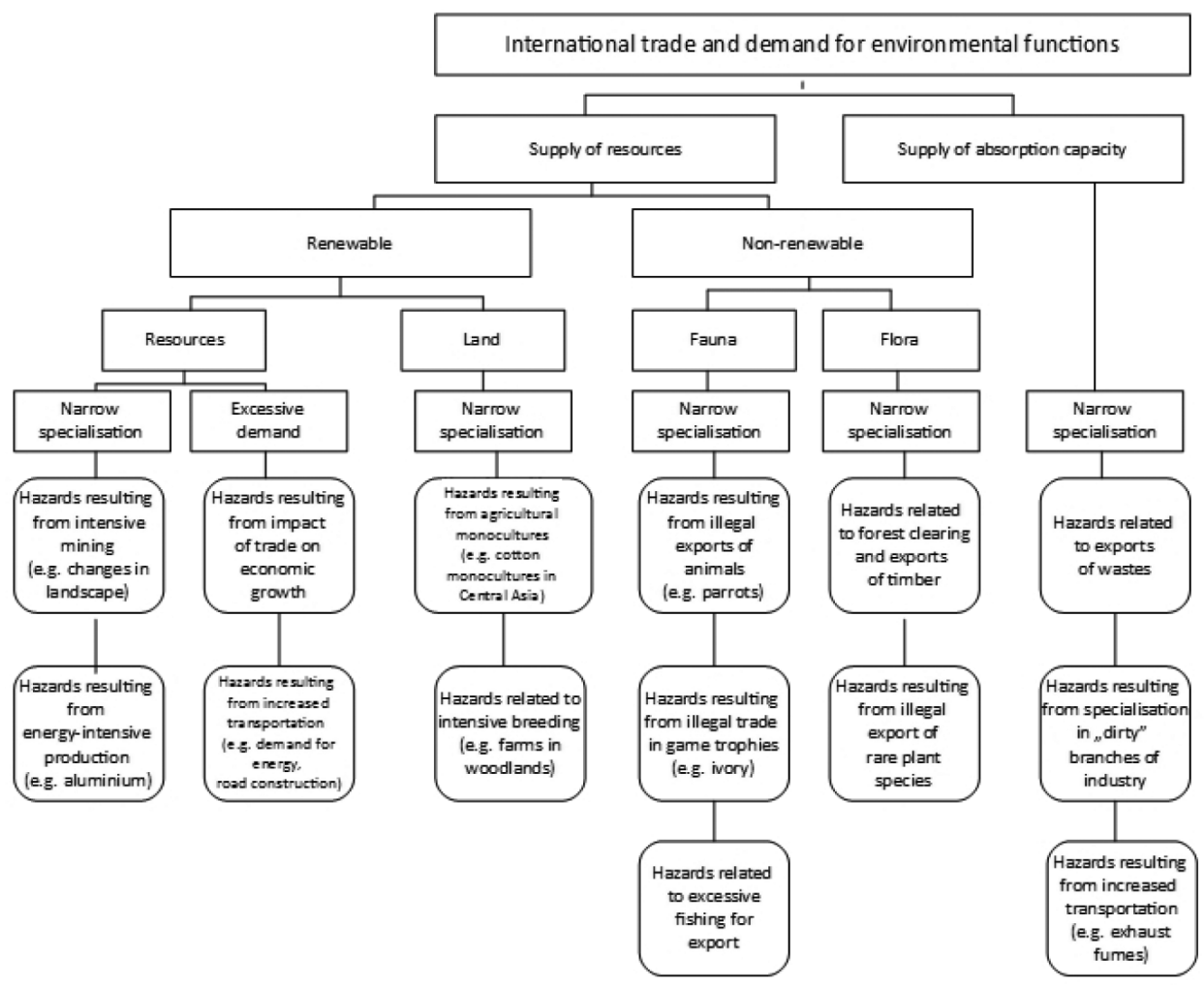

Figure 1.1. The environment and its primary functions

Source: Budnikowski (1998, p. 67)

renewable and non-renewable resources, so important for the management thereof. These are integral common goods that meet various individual and societal needs and the estimation of their 'natural' (market) price poses a number of problems. Even though theories have generated several approaches to the valorisation of, e.g., non-market renewable resources (the individual preferences theorem, the hedonist theorem as well as the contingent valuation and the alternative cost theorems), in most cases attempts at any valuation of these resources may raise serious doubts. ${ }^{2}$ The growing dependence among economies resulting from globalisation is accompanied by the interconnection of natural systems. Air and water know no borders, therefore, external effects may arise on an international scale. According to Budnikowski (1998, p. 64), the environmental impact

2 More on the subject in e.g. Szyszko et al. (2013). 
of international trade is well illustrated by Rees's (1992) metaphor of the 'ecological footprint'. It was defined as an area of closely interconnected areas of productive land and sea ecosystems required to produce the goods consumed and to assimilate the wastes generated. The ecological footprint at the beginning of the 1960s amounted to 0.49 , whereas in 2011 as much as 1.5, which means that the world population uses currently $150 \%$ of the earth capacities related to resource exploitation and pollution absorption. It should be stressed however, that during the last 40 years the ecological footprint measured in global hectares per 1 inhabitant of the Earth (the estimated number of hectares of land and sea surface needed to compensate for resources used for consumption of absorption of wastes) amounts to ca. 2.5-2.8 (footprintnetwork.org 2015).

\subsection{International trade and demand for resources}

The last decade is characterised by the fast growth in prices of resources in international trade, resulting from, among others, the demand of the so-called emerging markets. Dudziński (2013) calls this phenomenon the '21st century resources boom'. In international trade, we observe the growing demand for almost all kinds of resources, but mainly for energy resources. One of the outlooks by the World Bank suggests that by 2030 the demand for energy will have risen by over $120 \%$ (with $3 / 4$ of this growth to be consumed by developing countries), including the doubled demand for crude oil ${ }^{3}$ (Global Economic Prospects, Commodities and Crossroads 2009).

In today's world, a clearly visible shift in energy demand towards the nonOECD (most developed) countries can be observed. Is it estimated that energy consumption in these countries will grow by $2.3 \%$ annually by 2035 . To compare, growth in OECD countries should not exceed $0.2 \%$ between 2012 and 2035, with a strong declining tendency after 2030 (BP Energy Outlook 2035 2014, p. 9).

The depletion of basic natural resources (including raw materials and primary energy sources) is seen as a serious threat. The issue was very much highlighted in the 1970s, characterised by a serious energy and ecological crisis. The report Our common future (1987) stressed that prices of non-renewable resources would grow in parallel with their increasingly difficult accessibility. Moreover, the report contained a warning indicating that high levels of economic growth take

3 This assumption was made under the expectation that no progress will be made in energy generation efficiency. 
place at the expense of future generations, who will be forced to limit the consumption of some goods due to the depletion of resources. A number of countries suffering from a resource deficit try to secure their supplies in international markets. For example, the European Union opposes the impediments imposed on access to resources in third countries through the introduction of measures that distort free trade (European Parliament Resolution of 20 May 2008 on Trade in Raw Materials and Commodities 2009).

As already mentioned, a particularly important role is played by energy resources and primary energy carriers (e.g. crude oil, coal, natural gas and uranium). The key problem is that they cannot be recycled, and their exploitation results in the production of gas, dust and heat pollution. This, in turn, gives rise to ecological threats, e.g. the production of carcinogenic and flora-degrading dusts, the emission of gases producing acid rains and heat pollution. Metals, in turn, via their gasiforms and radioactive waste, affect human health and the quality of foodstuffs. The use of chemical resources results in disturbances in natural biogeochemical processes (Czaja 2002, p. 398).

\subsection{Impact of export promoting specialisations on the environment}

\subsubsection{Intensive agriculture and degradation of soil}

In underdeveloped countries, specialisation in production leads to degradation of soils, resulting from excessive intensification of agricultural production as well as its monoculture character. The processes observed in Central Asia are a good illustration of the thesis. Agriculture in countries of this region was once capable of feeding their population for a number of centuries. From the moment these countries got included in the centrally planned economy, traditional crops were replaced with the mass production of industrial crops (e.g. cotton), which led to considerable degradation of soil in these regions. Similarly, in a number of countries, the extraction of crude oil and natural gas results in significant devastation of the environment, in particular, pollution of large areas of soils and groundwater.

A number of hazards for the natural environment are caused by intensive farming. These result from the scale of crops or the demand for energy resources from the sector. Besides this, the intensification of farming, aimed at increased efficiency, causes excessive use of production means, such as agricultural machinery, mineral fertilisers or plant protection products. Excessive use of machinery may, for example, develop watertight layers of soils, which, in turn, result in their lim- 
ited aeration, permeability of water and filtration. Moreover, constant cultivation speeds up the oxidation of organic substances resulting in a decrease in its fertility.

Overly intensive agricultural production or export-oriented monocultures in agricultural practices (growing coffee, cocoa or cotton), replacing traditional and diversified agricultural production also contributes to overexploitation of the environment. Former USSR Republics, such as Uzbekistan or Turkmenistan, one of the world largest producers and exporters of cotton, provide a good example of areas characterised by monoculture practices.

\section{The impact of cotton production on the environment - the case of the Aral Lake}

The Aral Lake, situated on the Kazakhstan/Uzbekistan border, was formerly called the Aral Sea. It is a landlocked, saline, endorheic lake in the desert area of the Turan Lowland in Central Asia. Formerly supplied by two rivers, Amu Darya and Syr Darya, today it relies mostly on precipitation. There are numerous islands within the Lake's basin, with their number growing as the water level falls. The largest of them are: Vozrozhdeniya Island (translating into Rebirth or Renaissance Island), Barsa Kelmes and Kokaral.

The Aral Lake covers part of the Aral-Syrykamysh depression, stretching along the Eastern foot of the Ustyurt Plateau. The Aral Lake surroundings are amongst the most ecologically endangered areas in the world. The desiccation of the Aral Lake resulted from a major reshaping of the environment owing to the needs of the fast-developing Soviet industry. It affected mostly certain former USSR Republics, including Uzbekistan and Turkmenistan. The authorities of the newly-created Soviet Union, decided that the Karakum Desert area would become a cotton growing region. To this end, along both rivers feeding the lake, a number of irrigation channels were built, very often against the basic canons of hydrology. The obvious result of this irrational policy was the desiccation of the basin. Whereas in 1960 its surface amounted to $68 \mathrm{k} \mathrm{sq} . \mathrm{km}$, today its area has decreased by almost $90 \%$. Its bed nowadays forms a new desert, stretching between Uzbekistan and Kazakhstan.

Cotton growing in these countries has led to soil erosion, while attempts to irrigate fields with water from rivers - contributors to the Aral Lake - has led to a total destruction of the region's fauna and flora. A saline desert, with an area of over 40k sq. km, has replaced the former lake. Salty dust, travelling - depending on wind strength - as far as $500 \mathrm{~km}$ from the desert, also constitutes a hazardous factor, contributing to degradation and erosion of soils, thus leading to environmental disaster. Additionally, the mezoclimatic changes 
(towards a more continental climate) are now observed in the area, meaning that summer months get hotter and winters longer, which has also led to the shortening of the vegetation period. Growing salinity and shrinking water areas adversely affect local agriculture and diminish the productivity of the soil. The Amu Darya delta has been particularly badly affected: with forests growing along the river dying out. Continuous extension of artificially irrigated areas and dependence of cultivated crops on access to water lead to its excessive consumption, which, in turn, lowers the level of groundwater. This has become highly saline, toxic (due to excessive use of DDT and other harmful chemicals) and undrinkable. As a result of this unreasonable human activity, a number of fish species have also disappeared.

Source: Bielecki (2010).

\subsubsection{Deforestation}

Deforestation designed to create more arable land resulting from increased international trade constitutes another problem for the world economy. Rich literature on the subject clearly suggests that growing demand and prices (in international markets) for agricultural and timber industry products result in the broadening of deforested areas. The following authors provided analyses for individual countries: Angelsen (1999) - Tanzania, Arroyo-Mora at al. (2005) - Costa Rica, Pacheco (2004) - Bolivia, Morton et al. (2006) - Brazil or McAlpine (2009) - Australia.

Mass clearing of forests causes massive devastation in Africa, Caribbean and Pacific countries and Latin America. In many cases, this results from the activities of international companies interested in maximising profits and ignoring any side effects of their activities. The consequences of such behaviour affect not only the environment but - first and foremost - the economy. In some countries (e.g. in Nigeria or the Philippines) where exploitation of woodland resources by international corporations is intensive, deforestation has become a nation-wide problem. As a consequence, these countries not only lose the possibility to export forestry products, but also the jobs and income that might be generated by the forest and timber industry (Nordstrom, Vaughan 1999).

It is worth stressing, that in the last three decades ${ }^{4}$, the global area of forests has decreased by ca. 50\%. According to Laurance (2010, p. 73), 25 countries have

${ }^{4}$ Although deforestation concerns mostly tropical forests, the temperate zone's forests are also highly endangered. 
irrevocably lost their tropical forests, while other 29 states have lost over $90 \%$. The deforestation ratio is highest in Asia (40\%), followed by Central and South America and Africa. In some scarcely populated areas of South-East Asia, such as Borneo, Sumatra and New Guinea, forests have been replaced with oil palms and rubber trees plantations. It is also the case in Malaysia, Indonesia and Thailand, belonging to the largest exporters of both palm oil and natural rubber. In 2011, the share of Malaysia, Indonesia, Thailand and Vietnam in the total exports of natural rubber was as much as $87 \%$. (FAOstat 2014).

The gradual replacement of forests with industrial crops represents a considerable threat to the diversity of fauna species. This is particularly harmful in the case of tropical forests, being the natural habitat for ca. $60 \%$ of all animal species known. It is estimated that in the future ca. $40 \%$ of animal species typical of the so-called biodiversity hotspots ${ }^{5}$ will perish. According to BirdLife International, the same is deemed to happen - within the next century - with at least $13 \%$ of bird species, with $99 \%$ of them driven to extinction due to deforestation and hunting (Bradshaw et al. 2009, p. 81). Additionally, illegal international trade in rare animal species adds up to a decrease in the population of these fauna species.

\subsubsection{Destruction of mangrove forests}

Excessive specialisation of international trade contributes also to the destruction of other renewable resources. A good example may be provided by mass shrimp fishing (intended mainly for developed countries' markets), which brings about the extinction of mangrove forests in a number of developing countries, in particular those of the South-East Asia and East Africa. ${ }^{6}$ Destruction of these forests leads inevitably to the loss of the basic functions of ecosystems, being natural habitats of fish and crustaceans species already on the brink of extinction. Other endangered functions of the mangrove forests are these related to their participation in land-forming (epeirogenic) processes, protecting the land from storm surges and the absorption of a substantial amount of $\mathrm{CO}_{2}$ from the atmosphere.

The shrimp production industry has been exhibiting an upward tendency since the mid-20 $0^{\text {th }}$ century. In 1950 , global production of shrimps amounted to 1,325 tonnes, which made up only $0.3 \%$ of the total production of all crusta-

\footnotetext{
${ }^{5}$ A biodiversity hotspot - a region in which there are at least 1500 endemic species, that is ca. $0.5 \%$ of the world list of endemic species (total number of endemic species: 300 thousand).

${ }^{6}$ For the last ten years, the largest producers and exporters of, among others, shrimps and mussels include China, India, Bangladesh, Vietnam, Indonesia and Egypt.
} 
ceans originating mostly from coastal areas and rivers estuaries. Thirty years later, in 1982, global production of shrimps exceeded one million tons. By 2011, it had grown to almost 3.6 million tons, and represented $35 \%$ of global production of crustaceans both from fishing in seas and river estuaries (FAO 2015). It is estimated that ca. 1-1.5 mio. ha of global coastal areas are used for shrimp farming (intensive systems), with a severely degraded environment in $20-40 \%$ of these areas. Thailand is considered an extreme case, as the area of mangrove forests in the country was halved over the period 1960-1996. Ca. 200,000 hectares of mangrove forests ceased to exist, and one third of their area was transformed into shrimp farms. The negative effects of these farms can also be observed in other countries, inter alia, in Bangladesh, where since the early 1990s, specialisation in shrimp farming and their export has produced significant social, economic and environmental effects. These include, first and foremost, increased salinity, a dramatic drop in soil fertility, deforestation, irreversible destruction of coastal flora (mangrove forests included) and the disappearance of biodiversity (many species of flora and fauna, primarily fish).

The high concentration of organic compounds, chemicals and heavy metals, due to their intensive use in shrimp production, has led to eutrophication with an increased risk of harmful algal blooms, changes in the nutrition patterns of many marine animals, oxygen depletion (anoxia), toxicity of sulphite and nitrogen compounds (as a result of decomposition of organic matter), and increased morbidity (the low quality of sea water). All these developments have destabilised the coast, increased erosion and damaged coral reefs. Restoration of any eco-system is a long-term and often impossible exercise. Further negative consequences of industrial shrimp farming include the withdrawal from traditional business, such as growing rice or husbandry.

\subsubsection{Intense fishing}

Fishing as an export specialisation also adversely affects the environment. Nowadays, too much of the fish stock is still being overfished, above the maximum sustainable yield (MSY). This is the threshold which identifies the optimum annual catch that would not hinder future reproduction of fish stock. Exploitation of wild fish stocks for export purposes rapidly increased in the 1970s and 1980s, due to the development of fishing fleets, new fishing technologies and increased investments in the fisheries sector. By the end of the 1980s, despite increased fishing capacity, production of fish from wild fishing areas dropped or stagnated (Delgado et al., 2003, p. 2). By the late 1990 s, developing countries were producing twice as much fish as developed countries, which, to some extent, was the effect of the creation of exclusive economic zones based on the United Nations Convention on the Law of the Sea. 
According to Eurostat and FAO, the biggest global producers and exporters of fish are China (16.8\%), Peru (7.8\%), Indonesia and the EU27 (5.7\% each), the United States (4.7\%), and India (4.6\%) (Wspólna polityka rybołówstwa $w$ liczbach 2012, p. 20). Overexploitation of fishing grounds results in overfishing, which negatively impacts the environment. It causes reduced catches, a smaller average size of fish, increased by-catch or discards or reduced biodiversity in fresh and sea waters. Overfishing of at least one species distorts the balance in eco-systems, and stock restoration of late-maturing big fish species may take years. On top of that, the removal of older, bigger individuals with good reproductive capabilities reduces the regeneration capacity of the entire population. An example is the overfishing of cod in the North and Baltic Sea at the end of the $20^{\text {th }}$ century, which disturbed the environmental balance in these regions. Its disappearance from the top of the food chain, caused by overfishing, changed the structure of the trophic cascade. Populations of seals, smaller fish species, snow crab, and the northern prawn considerably increased, while the amount of small zooplankton decreased. The latter is decisive for the development of phytoplankton, a natural inhibitor of algal blooms. According to common opinion, both climate changes and cod overfishing are the main reasons for the extreme transformations in the sea eco-systems of the Atlantic, North and Baltic Sea (Greene et al. 2008, p. 34).

Since 1990, trade liberalisation has severely reduced biodiversity in seas and oceans as a result of the overfishing of many fish stocks. Detailed analysis of data for individual species indicates a decreased fish population at the top of the food chain, since they represent the highest market value. The biggest problem is connected with the maintenance of the stock of big predators, the most valuable from a commercial point of view. Their overfishing changes the structure of the population and increases interest in further links in the food chain (the so called "fishing down the food chain"). According to Brocki (2011, p. 181), numbers of predators in the Northern Atlantic over the last 50 years has decreased by $2 / 3$, and the trophic level of fish landed decreases by 0.1 every decade. Going down the sea food chain, results in harvesting less valuable species and exploitation of further stock. The disappearance of dominant species allows other species to grow and their abundance distorts the eco-system.

This problem may be solved by applying the rules of responsible fishing, defined as a situation when all components of the fisheries sector are sustainable. In 1995, at the FAO Conference in Rome, attended by 170 countries, the participants adopted a code that establishes the necessary framework for international and national efforts aimed at ensuring the lasting and sustainable exploitation of living resources of seas in harmony with the environment. At present, there 
are many Regional Fisheries Management Organisations (RFMO), international bodies set up by countries fishing in particular geographic areas. There are ca. 20 RFMOs, covering a major part of global waters. Their role consists of managing, protecting and sustainable exploitation of sea species covered by respective conventions.

\subsubsection{Mining and extracting of raw materials}

Mechanical transformations of the earth surface connected with mining and extracting also negatively impact the environment. Surface mining is the simplest method used to obtain raw materials. In Poland alone, this method is used to extract ca. 40 minerals, inter alia, sands, gravel, loam, building and road stone, limestone, marl, sulphur, and brown coal. Huge surface mines are scattered across all continents, mainly in Australia, U.S., Canada, Chile, Columbia, Russia, China, India, Zimbabwe, and Zambia (Czaja, Becla 2007, p. 181). Some of these countries are also global top coal exporters. For instance, over the period 2007-2011, the share of Australia and Indonesia in global exports of coal was $49.4 \%$. They are followed by Russia (11.1\%), United States (7\%), and Columbia (6.8\%). Detailed data are given in Figure 1.2.

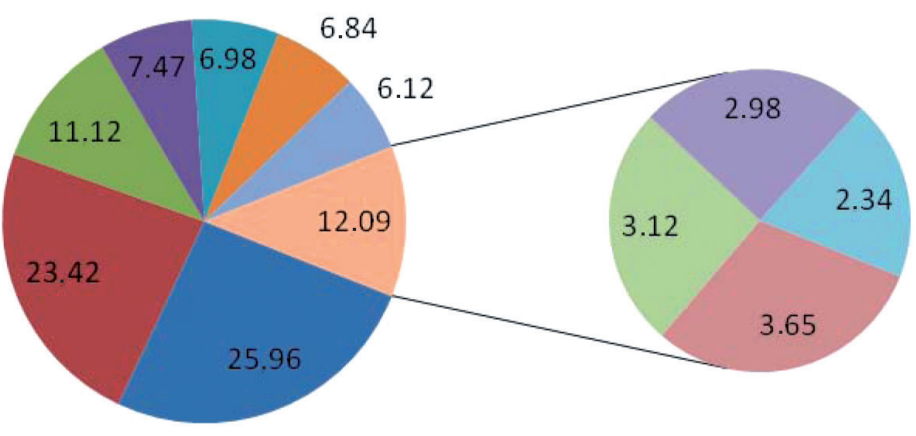

Australia

Indonesia

Russia

Other

United States

Colombia

South Africa

China

Canada

Kazakhstan

Vietnam

Figure 1.2. Share in global exports of coal in 2007-2012

Source: Author's own calculations based on International Energy Statistics, www.eia.gov (access: 22.07.2015) 
In the environs of mines, which often cover several hundred square kilometres, the environment is badly degraded. This is due to severe transformations caused by surface mining and includes changes in (Nietrzeba-Marcinonis 2007, pp. 7, 10):

- geological structure and relief; emergence of new forms of landscape, depletion of soil layers; erosion, degradation and devastation of soils;

- water management (distortions in ground water systems; changes in surface waters; water contamination; arid land);

- in flora and fauna (direct destruction of habitats; loss of flora and fauna; degradation of plants);

- in soil structure (degradation, devastation, distortion in levels and layers);

- microclimate;

- type of land use.

Mining also rules out large areas previously used for farming or forests and reduces arable land. In Australia, in Bowen (Queensland), the negative impact of dust, volatile greenhouse gases, noise and vibration was observed. In that region, mining threatens underground water as a result of drilling, underground exploitation of raw materials or as a result of draining shallow groundwater. Saline water is a side effect of mining and increases the danger of flood and contamination of local eco-systems. Subsidence results in the formation of hollows, which hinder farming. Additionally, widespread damage caused by mining can also be observed in fixed assets, buildings, and infrastructure. Similar threats can be identified in other regions of Australia, e.g., Hunter Valley or Gunnedah Basin (both mines are in the state of New South Wales) (Franks et al. 2010, pp. 301-304).

Another example is a surface mine in South Sumatra in Indonesia, where coal resources are among the biggest in the country (33\%, the second biggest). The vast majority of the extracted raw material is exported. The negative impact of mining and extracting is huge, which is reflected in the intense geomorphologic processes. Fatah conducted studies to answer the question of how the size of a mine and the scale of coal mining determines the environmental impact. We may expect that from the point of view of environmental protection, it is better to have many small mines which operate based on stringent regulations. Intensity of noise and transport should be reduced, together with soil degradation and erosion or costs of waste disposal. Calculations show however, that the contamination of the environment by each mine considerably burdens the environment and only marginally depends on size (Fatah 2008, pp. 95-97). The presence of 
many small mines instead of one larger one will not solve the problem of any harmful impact.

Oil mining also adversely affects the environment, as it strongly impacts all of its components, e.g., the relief, water management, atmosphere, soil and flora. For resources under the seabed, changes are produced to its surface and the quality of water and air. These may be of substantial size and provoke disastrous effects, in particular when there are eruptions of formation fluids and leaks of drilling fluid from wells made from drilling platforms and when there are failures of tankers or oil pipelines. Contamination of the atmosphere is down to dust pollutions and contamination with gases produced by combustion engines, boiler houses as well as transport, construction of pipelines, storing waste and technological material. According to Dubiel, Matyasik and Ziaja (2010), open leaks of hydrocarbons from oil wells, oil fires outside of pipelines and siphons in gas drillings pose the biggest danger. Other harmful effects of mining include noise, light and changes in temperature (Dubiel et al. 2010, p. 573). Air-born contamination degrades soil and flora.

\section{The environmental impact of the extraction of oil - the case of Nigeria}

Nigeria is one of the biggest producers and exporters of oil in Africa. According to the UN report, it is also one of the most contaminated areas of the world, due to the exploitation of the environment (United Nations 2007, p. 7). The mining sector in the Niger delta produces ca. $85 \%$ of the GDP of the country, and is the source of $95 \%$ of revenue to the national budget. Paradoxically, the region remains the poorest part of the country, mainly as a result of the environmentally unfriendly exploitation of oil and the policy of depriving the indigenous people of their rights to raw materials. It is estimated that since 1975 , over $80 \%$ of oil extracted in the region has been exported to foreign markets, and represented $90 \%$ of profits from exports in Nigeria (Ebegbulem et al. 2013, p. 279). This is the reason why the environment is degraded and why farmers' income has decreased over the entire area, which is confirmed by the studies of Inoni, Omotor, and Adun (2006) conducted on randomly selected households of 262 farmers from 10 communities in the region. Natural gas extracted together with crude oil burnt as flares releases dangerous hydrocarbons (methane mainly) with sulphur and nitrogen oxides into the atmosphere. As a result of these uncontrolled emission of gases, 35 mio. tons of $\mathrm{CO}_{2}$ were released to the atmosphere and ca. 12 mio. tons of methane, meaning "Nigerian oilfields contribute more to global warming than the rest of the world" (United Nations 2007, p. 7). Gas flares are fatal for agriculture. Studies demonstrate that they are responsible for $100 \%$ of productivity losses for crops situated within the range of ca. $200 \mathrm{~m}$ from the 
place of extraction (e.g., Izombe station), $45 \%$ of losses within $600 \mathrm{~m}$, and ca. $10 \%$ of losses in crops within the range of one kilometre. Most trees, e.g., oil palms or cotton bushes have died out completely as a result of air contamination and intense gas emissions (Ebegbulem et al. 2013, p. 282).

Sources: Inoni et. al. (2006), United Nations (2007), Ebegbulem et al. (2013).

\subsection{Dirty industry migration}

Recent decades have also witnessed discussion concerning the migration of industries in search of the lowest environmental standards. This migration is the effect of, inter alia, trade liberalisation, increased turnover in international trade and it deepens the differentiation in the environment in rich and poor countries. The so-called pollution havens hypothesis assumes that enterprises (especially emission intensive ones) aim to locate their business in poorly developed countries or areas where environmental requirements are low, to avoid the high costs of manufacturing. According to Chodyński (2011, p. 114), as many as $40 \%$ of projects are connected with operations potentially harmful to the environment. That is particularly true of: machinery, electronic appliances, chemical, food processing, non-ferrous metals, mineral products, man-made plastics, and rubber industries or transportation services. We cannot but agree, as the above mentioned industries exploit the environment to the greatest extent and contribute to its faster degradation. That is caused by the liberalisation of the world economy, where free movement of goods and elimination of barriers to trade are the most important aspects. Moreover, the organisation of production processes, where ownership surveillance is within individual links of the value chain, is being replaced with a system of contracts. International enterprises avoid engaging their resources in buying out and reorganising other entities as they want to avoid the risk of operating in a new environment. Guided by the "do it the cheapest" principle they can quickly and cheaply change suppliers, often during their "environmental exploitation" of subsequent regions.

On top of that, dominating interests of international corporations often make local and national initiatives designed to enforce environmental rules look repressive or unfriendly. The competitive struggle for profit produces reflections of "disaster capitalism", where disasters are used to achieve individual objectives at the expense of societies and the natural environment.

Enterprises which take advantage of the freedoms of an open market to migrate in the search for less stringent environmental standards may be justified in 
many ways. Firstly, stringent environmental regulations significantly increase the cost of production, as they often require technologically advanced equipment and solutions. They increase the cost of manufacturing, mainly due to changes required in production technology or the installation of cleaning or filtering devices. Manufacturers will avoid higher charges if they don't implement costly, environmentally friendly technologies. Secondly, stringent environmental regulations limit the possibilities of disposing of industrial waste (deplete ravaged areas that could be used as waste landfills). Thirdly, environmental standards may lead to a ban on the use of some (toxic for the environment) factors of production as well as certain outcomes of production. In all of these cases, increasing the cost of manufacturing is the issue of primary importance. Hence, it is obvious that enterprises are interested in locating manufacturing in regions offering lower costs of production (assuming it is feasible and other determinants of the location remain the same). Low standards expected from, e.g., production methods diversify conditions in different countries and, by the same token, determine location decisions. This is in line with the microeconomic principle of cost minimisation. Moving production to less environmentally demanding countries to be able to use a cheaper but more contaminating technology is an example of eco-dumping. As a result, the environment is badly degraded, natural resources are freely exploited, risk of illnesses and death rate increase and the standard of living of the local community deteriorates. It is controversial and causes protests among environmentalists and economists.

Moving burdensome production to countries of lower standards and environmental regulations also means contamination is transferred internationally and intensifies global environmental problems. "Dirty" investment means also shifting environmental risk on to weaker partners, which is often referred to as environmental neo-colonialism (eco-imperialism). Czaja (2004, p. 11) defines it as a phenomenon where enterprises from developed countries locate outdated production technologies, store waste and pollution costly in disposal or overexploit raw materials in developing countries. Besides this, eco-imperialism means also additional environmental duties imposed by developed countries that hinder social and economic development of developing countries without proper logistics and financial support. On the other hand, however, from an economic point of view, it seems undisputable that allocation of industries caused by differences in standards is optimal. It helps countries to exploit or generate their comparative advantages. Moreover, one may not dismiss that moderate environmental requirements result from the lobbying of groups hoping to attract foreign investors as poorly developed countries compete for industrial investment projects, even in sectors that have been eliminated in highly developed countries for environmental reasons. 
Many of these poorly developed countries still specialise and export products, the production of which intensely contaminate the environment. Usually this is true of Africa, South America, or Asia. Exploitation of non-renewable raw materials and their processing provides the basis for operations of the most heavily polluting sectors of industry. Moreover, any increase in exports of renewable resources from developing countries recorded in statistics is also linked with the development of non-organic farming, which destroys biodiversity and valuable natural habitats. The above examples demonstrate that trade liberalisation in these countries may intensify environmental degradation, similarly to the inflow of foreign direct investment motivated by dirty production. Obviously, we may not prejudge whether that will really be the case, although intuition suggests such an ending.

The issue of dirty industry migration has long been a subject of interest to economists. However, literature remains divided over the effects of liberalisation, which apparently contributes to migration in the search for moderate environmental standards. While theoretical writings are dominated with voices that justify such trends, conclusions from empirical models are ambiguous.

\subsection{Transportation and the environment}

The increasingly higher volume of cargo transport at a global scale is the effect of trade development. It is also accompanied by the extension of distances covered by goods and focused on modes of transport more burdensome to the environment. In the modern economy, transport is the most important sector. Its infrastructure covers ca. $1 \%$ of the globe (Czaja, Becla 2007, p. 183). The dynamic development of transport in recent decades resulting from intensified trade is a vital development factor in the world. At the same time, however, it is a source of burden and environmental problems that can be observed not only locally but also globally. Its energy consumption (fuels and electricity) is substantial and it exerts great pressure upon the environment. Liberalisation of trade and its increased volumes intensify international industrial cooperation, which calls for the movement of raw materials, parts, semi-finished products and ready goods to various countries and continents. Over the period 1990-2010, the value of global trade in goods increased by $370 \%$, with an average annual increase of ca. $9 \%$. In 2012, the share of transportation services in total exports of services, on average globally, amounted to $22.35 \%$ (www.dataworldbank.org, 2015).

The European Commission forecasts until 2030 show that transport (both passenger and cargo) will continue to develop dynamically. The market for the 
transport of goods will grow at a faster pace, since it is closer correlated with GDP growth dynamics. In Europe, by 2030, the TEN-T programme will partially be completed and is aimed at supporting the development of trans-European transport networks in a way respectful of the environment and offering higher safety standards. It is estimated that in the period 2010-2050, transport of goods will increase by $57 \%$ (an annual average of 1.1\%). The biggest increase of $72 \%$ (corresponding to $1.4 \%$ annually) will be recorded in Member States which joined the EU after 2004 (EU Energy 2014, pp. 38-39).

Hence, it seems obvious that with the constantly increasing market of transport services, following in the footsteps of increasing tendencies in trade, its environmental impact will be greater. This is due to the direct environmental effect of transport. Its consequences depend on the level of economic development of countries, advancements in technology, and the ability to exploit various modes of transport as well as the climate and sensitivity of environmental components. The transport infrastructure exerts pressure upon natural habitats and biodiversity as a result of land use, distortions caused by noise and light or landscape transformations. It is also the major cause of accidents. Increased negative impacts are also due to changes in the means of transport.

Globalisation requires rapid movements of goods, which leads to increased consumption of energy and intense emission of pollution. The economy encourages supply management procedures, such as Just In Time, which, on the one hand, eliminate inefficiencies by reducing the lead time to a minimum but, on the other hand, need quick, i.e. energy-consuming, means of transport. On an international scale the roles of rail and inland transport relatively diminish, while air and, most of all, road transport have become more important.

Van Veen-Groot and Nijkamp (1999) discuss the environmental impact of transport by means of four effects: scale, structural, technical and product. The first one reflects the impact of trade liberalisation upon economic activity. It is linked to increases in international trade, meaning an increase in transport and a higher demand for transport services. As the latter poses a big burden to the environment, it is postulated to use intermodal transport more broadly (although not always and not under all circumstances is it the easiest solution). Striving to use less polluting modes of transport (such as rail or inland waterways instead of road or air transport) could be a solution leading to reduced emissions of pollutants per unit of product. Recently, we can observe opposite tendencies: the shift from slower means of transport towards faster but less environmentally-friendly ones.

The structural effect demonstrates the impact of trade liberalisation upon increases in production in sectors in which a country enjoys a comparative advantage. The effect may produce changes in the structure of economic activity, 
e.g., in the share of industrial production, agriculture or services in GDP as well as transformations within individual sectors. Hence, trade liberalisation may favour expansion of economic activities in line with identified comparative advantages, such as climate or applied environmental standards. If environmental resources are correctly valued, their value is taken into account in international markets and exploitation is not distorted with state intervention, trade generates conditions conducive to sustainable growth. If these ideal premises are missing, it may produce negative structural changes by increasing specialisation in "non-environmentally-friendly" sectors. In looking for better (cheaper) operating conditions, industries start moving and the structure of economies will change, generating increased demand for transport.

Over the last few years, the average distance covered by transport has considerably increased and, despite becoming a day-to-day reality, new technologies in transport and logistics are insufficient to fully offset the negative impact of trade upon the environment. The increased average distance over which goods are transported goes against the principle of sustainable growth, according to which, production and consumption were closest in terms of geography. On top of that, structural effects include the features of transported products. In the contemporary economy, small products representing high added value are transported. They can be easily transported by air or by road (in this case they are mainly a so-called general cargo), modes that produce more contamination.

The technical effect, contrary to the previous two, has a positive impact upon the environment. It modifies technologies, reflects potential transfer of innovation, expands uses of environmentally-friendly materials and, with respect to transit, it favours production of means of transport that produce less exhaust fumes and noise and are more energy-saving. Newer technologies are less burdensome to the environment. They also help to develop safety devices that can neutralise adverse outcomes of both previous effects.

The product effect, the last on the list, appears when products exert an environmental impact. This may be positive when more environmentally aware consumers select "green" goods and their preferences and higher expectations actually contribute to the dissemination of new, environmentally-friendly technologies. Innovations are a good example if they lead to the use of renewable sources of energy or place more environmentally-friendly cars in the market. Open trade, new investment, transfer of modern technologies or improved management systems help accelerate economic growth. On the other hand, however, the product effect may produce negative effects, e.g., when international trade facilitates the movement of dangerous or toxic materials. Negative outcomes include situations when trade liberalisation generates a demand for endangered 
species of flora and fauna. Can the wish to buy certain products (in line with consumer expectations) produce changes in transport? There are specific means of transport used for specific assortments of goods. Van Veen-Groot and Nijkamp (1999) demonstrate that products representing higher value (and smaller quantities) are transported using more environmentally-friendly means of transport, while cheaper goods (in bigger quantities) are transported in ways more harmful to the environment, which is why the increasing number of cheap products in international trade may generate more pollution. This is how positive quantitative effects of changes in the assortment of products are offset by unfavourable changes in the structure of the means of transport used to transport them.

Eurostat estimates show that in the years 1990-2011, emissions of harmful substances from transport increased by $19 \%$. The biggest increase in pollution was recorded for road transport (21\%), while a drop (-46\%) was identified for rail transport. Among EU Member States, the highest amount of harmful emissions was reported for Germany (17\% share in total EU emissions), followed by France (14\%), Italy (13\%), and the UK (12\%) (Energy, transport and environment indicators 2013, p. 141). These countries are also among the biggest exporters and importers, not only in the EU but also globally (Tables 1.1. and 1.2.).

Table 1.1. Key exporters in global trade in goods in 2012 (in bn of USD)

\begin{tabular}{|c|c|c|c|}
\hline Global ranking & Country & value in USD & $\begin{array}{c}\text { Percentage share in global } \\
\text { exports }\end{array}$ \\
\hline 1. & China & 2,049 & 11.1 \\
\hline 2. & United States & 1,546 & 8.4 \\
\hline 3. & Germany & 1,407 & 7.6 \\
\hline 6. & France & 569 & 3.1 \\
\hline 9. & Italy & 501 & 2.7 \\
\hline 11. & United Kingdom & 474 & 2.6 \\
\hline
\end{tabular}

Source: WTO Statistics database.

According to Badyda (2010), transport in the European Union is the source of almost $54 \%$ of total emissions of nitrogen oxides, $45 \%$ of $\mathrm{CO}_{2}, 23 \%$ non-methane volatile organic compounds, and $23 \%$ of dust $\mathrm{PM}_{10^{\prime}}$ and $28 \%$ of $\mathrm{PM}_{2,5}{ }^{7}$. More-

7 Solid particles of the diameter of 10 and $2,5 \mu \mathrm{m}$ respectively. 
over, it is responsible for the emission of over $41 \%$ of tropospheric ozone precursors, $23 \%$ of $\mathrm{CO}_{2}$ emissions, and almost $20 \%$ of other greenhouse gases (Badyda 2010, p. 115). Transport is the second biggest source of pollution emission in the $\mathrm{EU}$ (after the energy sector) and despite EU political initiatives and various legal regulations, pollution continues to increase. In the age of technological progress or the development of modern transportation networks, this may seem strange. Unit transport is less polluting, more energy-saving but still it depends $96 \%$ on oil and oil derivatives. We must admit that over the years transport and fuel technologies have become more environmentally friendly, nevertheless, the majority of trucks are powered by diesel engines, the main sources of emission of nitrogen oxides, solid particles and $\mathrm{CO}_{2}$ (Demir et al. 2013, p. 2). Therefore, although emissions per unit of transport are actually reduced, the increased number of vehicles and massive transport prevent total pollution from falling.

Table 1.2. Key importers in global trade in goods in 2012 (in bn of USD)

\begin{tabular}{|c|c|c|c|}
\hline Global ranking & Country & value in USD & $\begin{array}{c}\text { Percentage share in global } \\
\text { exports }\end{array}$ \\
\hline 1. & United States & 2,336 & 12.6 \\
\hline 2. & China & 1,818 & 9.8 \\
\hline 3. & Germany & 1,167 & 6.3 \\
\hline 5. & United Kingdom & 690 & 3.7 \\
\hline 6. & France & 674 & 3.6 \\
\hline 11. & Italy & 487 & 2.6 \\
\hline
\end{tabular}

Source: WTO Statistics database.

The deteriorating quality of the natural environment is especially painful to people living in agglomerations and alongside arterial roads. Hence, environmental aspects produce the need to promote environmentally-friendly modes and technologies of transport, including combined and intermodal transport. ${ }^{8}$ These needs have been reflected in many EU documents (e.g., the White Paper

8 Intermodal transport involves using multiple modes of transportation to carry goods in one cargo unit using at least two modes of transport one after another. Combined transport is intermodal transport with the main part of goods transported by rail, inland or sea waters, with only small fraction, at the beginning and/or the end performed on roads. 
of 2001), which state that the directions of European Transport Policy should be subordinated to the principle of sustainable growth and sustainable mobility, in particular, that of goods.

The scale of the problems resulting from transport is extensive. Remedies are connected with the development of more modern, environmentally-friendly means of transport, both by improving those already existing and developing new ones. Changes also include transport management systems, disseminating new solutions (e.g., the already mentioned intermodal transport), and integrated logistics.

Until the 1970s, the issues of the environmental effects of trade and intensified consumption were neglected because already industrialised countries had been building up their wealth based on the least costly use of natural resources in distant parts of the world. Overexploitation thereof results in lasting changes in eco-systems, while free trade produced considerable negative effects in exporting countries. Arguments in favour of government interference in international trade and more and more vocal postulates in favour of environmental protection, have become the subject of debate on the contemporary global economy and the interdependence of regions.

Trade expansion targeting global demand changes the scale at which enterprises operate, production organisation and directions of supplies. International trade and, first and foremost, production, overburden the environment and strongly impact its resources. Agricultural use of land to grow more and more crops, excessive extraction of natural resources, storing toxic and radioactive waste, etc. give credibility to such views. Environmental issues emerging as a result of such activities include mainly deforestation, rapid desertification of large areas in all continents, contamination of seas and oceans, overfishing or progressing degradation of soil. Pollutants reduce biodiversity, in terms of species and habitat. Increased pressure on the environment also results from increasing greenhouse gases emissions, leading to changes in climate or distorting the balance in eco-systems. As a result, the "environmental footprint" has doubled within the last 50 years, while the "carbon footprint"9 has increased almost tenfold.

9 Carbon footprint is a methodology of estimating total emissions of GHG in equivalents of carbon for a product's life cycle from the moment raw materials are obtained, thorough manufacturing until the disposal of the final product (www.carbontrust.co.uk 2015). 
Environmental pollution issues have accompanied discussions on world trade liberalisation for many years. The view that trade negatively impacts the environment is commonplace. However, we need to stress that the impact of international trade upon the quality of the environment and the quality of its components is usually indirect. For that reason, it is difficult to identify it and estimate.

\section{Questions and assignments}

1. List three characteristic features of contemporary international trade.

2. Describe the demands of international trade on the main functions of the environment.

3. Evaluate the environmental impact of production for export. Give examples.

4. Describe the environmental effects of transport.

5. Evaluate the phenomenon of dirty industry migration.

\section{Literature}

Angelsen A. (1999), Agricultural expansion and deforestation. Modelling the impact of population, market forces and property rights, "Journal of Development Economics", vol. 58(1), pp. 185-218.

Arroyo-Mora J.P., Sánchez-Azofeifa G.A., Rivard B., Calvo J.C., Janzen D.H., Dynamics in landscape structure and composition for the Chorotega region, Costa Rica from 1960 to 2000, "Agriculture, Ecosystems and Environment", vol. 106(1), pp. 27-39.

Badyda A.J. (2010), Zagrożenia środowiskowe ze strony transportu, "Nauka”, nr 4, pp. 115-125.

White Paper. European Transport Policy 2010 (2001), European Commission, Brussels.

Bielecki R. (2010), Jezioro Aralskie - największa katastrofa ekologiczna minionego stulecia, Annales Universitatis Paedagogicae Cracoviensis, Studia Geographica I, Przyrodnicze skutki antropopresji, Folia 93, pp. 6-13.

BP Energy Outlook 2035, 2014.

Bradshaw C.J.A., Sodhi N.S., Brook B.W. (2009), Tropical turmoil: a biodiversity tragedy in Progress, "Frontiers in Ecology and the Environment", vol. 7(2), pp. 79-87.

Brocki W. (2011), Odpowiedzialne rybołówstwo w świetle ekonomii zrównoważonego rozwoju, [in:] Poskrobko B. (ed.) Ekonomia zrównoważonego rozwoju w świetle kanonów nauki, Wyższa Szkoła Ekonomiczna, Białystok, pp. 175-188. 
Brundtland G.H. (1987), Our Common Future, World Commission on Environment and Development), Oxford University Press, Oxford 1987.

Budnikowski A. (1998), Ochrona środowiska naturalnego jako problem globalny, PWE, Warsaw.

Chodyński A. (2011), Odpowiedzialność ekologiczna w proaktywnym rozwoju przedsiębiorstw, Krakowska Akademia im. Andrzeja Frycza Modrzewskiego, Krakow.

Common Fisheries Policy in numbers. Basic statistical data (2012), European Union, Belgium.

Czaja S. (2002), Internacjonalizacja i globalizacja współczesnego kryzysu ekologicznego, [in:] Fiedor B., Czaja S., Graczyk A., Jakubczyk Z., Podstawy ekonomii środowiska i zasobów naturalnych, C.H. Beck, Warsaw, pp. 382-400.

Czaja S. (2004), Wpływ współczesnego neokolonializmu ekologicznego na globalizację problemów środowiskowych, [in:] Ochrona środowiska a procesy integracji i globalizacji, eds. A. Budnikowski, M. Cygler, Oficyna Wydawnicza SGH, Warsaw.

Czaja S., Becla A. (2007), Ekologiczne podstawy procesów gospodarowania, Wyd. Akademii Ekonomicznej im. Oskara Langego we Wrocławiu, Wroclaw.

Czaja S., Becla A. (2007), Ekologiczne podstawy procesów gospodarowania, Wyd. Akademii Ekonomicznej im. Oskara Langego we Wrocławiu, Wroclaw.

Delgado Ch.L., Wada N., Rosegrant M.W., Meijer S., Ahmed M. (2003), Fish to 2020. Supply and demand. Changing global markets., International Food Policy Research Institute Washington, D.C., WorldFish Center Penang, Malaysia.

Demir E., Bektas T., Laporte G. (2013), A Review of Recent Research on Green Road Freight Transportation, "Beta Working Paper series" 428, August, pp. 1-40.

Dubiel S., Matyasik A., Ziaja J. (2010), Systematyka wpływów górnictwa ropy naftowej i gazu ziemnego na środowisko naturalne, „Wiertnictwo Nafta Gaz”, vol. 27(3), pp. 571-582

Dudziński J. (2013), Kryzys surowcowy, paliwowy i żywnościowy lat 70. XX wieku a boom surowcowy XXI wieku - podobieństwa i różnice, „Studia i Prace Wydziału Nauk Ekonomicznych i Zarządzania", No. 33, pp. 19-33.

Dugiel W. (2009), Zmiany w światowym systemie handlu Perspektywa dla Unii Europejskiej, Centrum Europejskie Natolin, Warsaw.

Ebegbulem J.C., Ekpe D., Adejumo T.O. (2013), Oil Exploration and Poverty in the Niger Delta Region of Nigeria: A Critical Analysis, "International Journal of Business and Social Science", vol. 4(3), March, pp. 279-287.

Energy, transport and environment indicators (2013), Eurostat, Luxembourg.

EU Energy, Transport And GHG Emissions Trends To 2050 (2014), Reference Scenario 2013, European Commission, EU.

Fatah L. (2008), The Impacts of Coal Mining on the Economy and Environment of South Kalimantan Province, "Indonesia ASEAN Economic Bulletin", vol. 25(1), pp. 85-98

Franks D.M., Brereton D., Moran Ch.J. (2010), Managing the cumulative impacts of coal mining on regional communities and environments in Australia, "Impact Assessment and Project Appraisal", vol. 28(4), pp. 299-312.

Global Economic Prospects, Commodities and Crossroads (2009), World Bank, Washington. 
Greene Ch.H., Pershing A.J., Cronin T.M, Ceci N. (2008), Arctic Climate Change And Its Impacts On The Ecology Of The North Atlantic, "Ecology", vol. 89, pp. S24-S38.

Inoni O.E., Omotor D.O., Adun F.N. (2006), The Effect Of Oil Spillage On Crop Yield And Farm Income In Delta State, Nigeria, "Journal Of Central European Agriculture", vol. 7.(1), pp. 41-48.

International Energy Statistics, www.eia.gov. (access: 30.08.2015).

Jakubczyk Z. (2002), Teoretyczne podstawy gospodarowania zasobami naturalnymi, [in:] Fiedor B., Czaja S., Graczyk A., Jakubczyk Z., Podstawy ekonomii środowiska i zasobów naturalnych, C.H. Beck, Warsaw, pp. 120-169.

Laurance W.F. (2010), Habitat destruction: death by a thousand cuts, [in:] Sodhi N.S., Ehrlich P.R. (eds.), Conservation Biology For All, Oxford University Press, pp. 73-87.

McAlpine C., Etter A., Fearnside P., Seabrook L., Laurance W. (2009), Increasing world consumption of beef as a driver of regional and global change: a call for policy action based on evidence from Queensland (Australia), Colombia and Brazil, "Global Environmental Change", vol. 19(1), pp. 21-33.

Michalczyk B. (2007), Międzynarodowa wymiana towarowa, [in:] Współczesne tendencje w handlu międzynarodowym, Rymarczyk J., Niemiec M. (eds.), Oficyna Wydawnicza Arboretum, Wroclaw, pp. 39-75.

Morton D., DeFries R., Shimabukuro Y., Anderson L., Arai E., del Bon Espirito-Santo F., Freitas R., Morisette J. (2006), Cropland expansion changes deforestation dynamics in the southern Brazilian Amazon, "Proceedings of the National Academy of Sciences of USA", vol. 103(39), pp. 14637-14641.

Nietrzeba-Marcinonis J. (2007), Wpływ rekultywacji leśnej terenów pokopalnianych na wybrane właściwości gleb inicjalnych na przykładzie zwałowiska nadkładu Kopalni Węgla Brunatnego Turów S.A., PhD thesis, Uniwersytet Zielonogórski, Zielona Góra. Nordstrom H., Vaughan S. (1999), Trade and Environment, WTO Special Studies 4, Geneva. Pacheco P. (2006), Agricultural expansion and deforestation in lowland Bolivia: the import substitution versus the structural adjustment model, "Land Use Policy", vol. 23, pp. 205-225.

Rees W. (1992), Ecological footprints and appropriated carrying capacity: what urban economics leaves out?, "Environment and Urbanisation”, vol. 4(2), pp. 121-130.

Resolution of the European Parliament of 20.052008 on trade in primary raw materials and products (2008/2051 (INI)) 19.11.2009, Official Journal of European Union C $279 \mathrm{E} / 9$.

Szyszko J., Rylke J., Jeżewski P., Dymitryszyn I. (eds.) (2013), Ocena i wycena zasobów przyrodniczych, Wydawnictwo SGGW, Warsaw.

United Nations, Department Of Economic And Social Affairs (2007), The Adverse Impacts of Oil Pollution on the Environment and Wellbeing of a Local Indigenous Community: The Experience of the Ogoni People of Nigeria, Khabarovsk, Russian Federation, August.

van Veen-Groot D.B., Nijkamp P. (1999), Globalisation, transport and the environment: new perspectives for ecological economics, "Ecological Economics", vol. 31, pp. 331-346. 
www.carbontrust.co.uk. (access: 30.08.2015).

www.dataworldbank.org. (access: 30.08.2015).

www.faostat.fao.org. (access: 30.08.2015).

www.footprintnetwork.org. (access: 30.08.2015).

www.trademap.org. (access: 30.08.2015).

www.wto.org. (access: 30.08.2015). 
Considering environmental protection requirements in business operations may, in the long run, determine if a lasting comparative advantage can be achieved. That is why our textbook, rich in case studies, identifies not only the threats a business may pose to the environment but stresses the ways of reducing its negative impact. It discusses, among other things, the concept of corporate social responsibility, environmental management systems, methods and the importance of eco-labelling goods and the so called green public procurement in the private and public sectors. The book is addressed primarily to students of courses in economics and management. We hope it will also make interesting reading for entrepreneurs, representatives of business environment organisations and the staff of public administration at different levels.

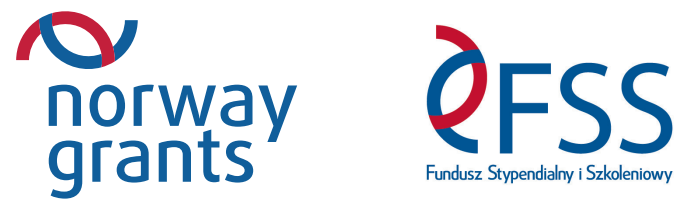

Project: The creation of new interdisciplinary curricula in the field of economics of environmental protection (in Polish and English) at the University of Łódź. Project supported by a grant from Norway through the Norway Grants and co-financed by the Polish funds.

The aim of the project is to improve the knowledge and awareness of Polish and foreign students, the faculty and alumni of the University of Łódź in the fields of sustainable development, ecology, international business and finance.

Grant amount: 533083 PLN 